\title{
PENGEMBANGAN MODEL SOCIOCULTURE-BASED NARRATIVE UNTUK KOMPETENSI MENULIS MATA KULIAH BAHASA INGGRIS DI PGSD
}

\author{
Ali Mustadi \\ FIP Universitas Negeri Yogyakarta \\ email: aly_uny@yahoo.com
}

\begin{abstract}
Abstrak
Penelitian ini bertujuan menghasilkan model Socioculture-Based Narrative untuk kompetensi menulis berbasis kompetensi komunikatif pada mata kuliah bahasa Inggris di PGSD. Penelitian ini merupakan penelitian pengembangan yang menggunakan model Borg \& Gall dengan empat tahapan, yakni: eksplorasi, pengembangan model dan penilaian ahli, pengujian model, dan validasi. Hasil penelitian sebagai berikut. Pertama, model yang dikembangkan telah memperhatikan empat aspek kompetensi komunikatif, yaitu: grammatical competence, sociolinguistic competence, discourse competence, dan strategic competence. Kedua, berdasarkan penilaian ahli, desain pembelajaran yang dikembangkan dinilai layak untuk meningkatkan kemampuan menulis mahasiswa di PGSD. Ketiga, hasil uji coba produk menunjukkan bahwa desain ini efektif dalam meningkatkan kemampuan menulis mahasiswa. Keempat, hasil analisis uji-t menunjukkan adanya pengaruh positif dan signifikan penerapan model yang dikembangkan terhadap peningkatan keterampilan menulis karangan naratif mahasiswa PGSD.
\end{abstract}

Kata kunci: socioculture-based narrative, kompetensi menulis, kompetensi komunikatif

\section{DEVELOPING A SOCIOCULTURE-BASED NARRATIVE MODEL FOR THE WRITING SKILL IN THE ENGLISH SUBJECT AT PGSD}

\begin{abstract}
This study aims to produce a Socioculture-Based Narrative model for the writing skill based on communicative competence in the English subject at PGSD. This was a research and development study employing the model by Borg \& Gall consisting of four stages, i.e.: exploration, model development and expert judgment, model tryout, and validation. The results are as follows. First, the developed model has taken into account of the four communicative competence aspects, i.e.: grammatical competence, sociolinguistic competence, discourse competence, and strategic competence. Second, based on expert judgment, the developed learning design is appropriate to improve PGSD students' writing skill. Third, the results of the product tryout show that the design is effective to improve students' writing skill. Fourth, the results of the t-test show a significant positive effect of the application of the developed model on the improvement of PGSD students' narrative writing skill.
\end{abstract}

Keywords: socioculture-based narrative, writing skill, communicative competence

\section{PENDAHULUAN}

Pendidikan merupakan aset peradaban, tak terkecuali Bahasa Inggris. Tanpa kemampuan berbahasa Inggris masyarakat
Indonesia akan mendapatkan kesulitan bersaing dengan masyarakat global (Alwasilah, 1997:89). Mahasiswa PGSD sebagai calon guru profesional di masa depan 
diharapkan mampu menguasai bahasa Inggris secara aktif baik written maupun spoken.

Oleh karena fungsi bahasa Inggris dan peran pendidik yang penting itu, pengembangan model pembelajaran bahasa Inggris yang tepatakan memberikan sumbangan besar dalam rangka meningkatkan mutu kualitas pembelajaran bahasa Inggris di PGSD. Tidak terkecuali bagaimana mendesain pembelajaran yang berkualitas bagi calon guru tingkat dasar di PGSD sangat mutlak diperlukan. Sebagaimana dikatan oleh Vargas-Hernandez (2013:75) bahwa "the implementation of a strategic management approach in basic education can lead institutions to achieve continuous quality education. Lebih khusus, pengembangan model ini memiliki keuntungan ganda. Pertama, peningkatan keterampilan bagi dosen dalam mengelola proses belajar mengajar dan mengembangkan diri sendiri dalam pembelajaran yang sesuai dengan kebutuhan dan lingkungan mahasiswa. Kedua, peningkatan kompetensi mahasiswa dalam berbahasa secara komunikatif dalam berbagai domain pemakaian bahasa, baik yang bersifat reseptif (menyimak dan membaca) maupun yang bersifat produktif (berbicara dan menulis) sesuai dengan pradigma pembelajaran bahasa untuk anak (English for children) dimana mahasiswa PGSD merupakan calon guru di tingkat SD.

Dalam perspektif pembelajaran bahasa Inggris untuk anak-anak (English for children) perlu dicermati situasi bahasa tersebut diajarkan dan lingkungan bahasa (linguistics environment) yang menjadi latar belakang pembelajarannya. Untuk itu, metode pembelajaran yang diberikan bersifat khusus (English for Children). Kekhususan pembelajaran bahasa Inggris ini dapat diwujudkan dengan mengedepankan kondisi sosiokultural sesuai tempat pembelajaran itu dilakukan. Hal itu sesuai dengan pernyataan Irine (2013: 92): "building the culture competence becomes an important prerequisite in managing the primary education's problem, both structural and cultural dimension".

Sehubungan dengan kondisi itu, pengembangan model bahasa Inggris harus diupayakan sesuai dengan konteks lingkungan sosiokultural peserta didik dengan mengacu pada paradigma pembelajaran komunikatif dan pembelajaran bahasa untuk anak-anak (English for children). Harapannya, kompetensi mahasiswa dalam bahasa Inggris relevan dengan kebutuhan komunikatif dan berorientasi pada kecakapan hidup yang relevan.

PGSD sebagai institusi pendidikan yang menyiapkan para calon guru profesional di tingkat SD di masa yang akan datang harus mampu menjawab tantangan yaitu mampu mengembangkan segala potensi peserta didik termasuk potensi bahasa Inggris secara baik dan berkualitas. Berdasarkan beberapa penelitian terkait di antaranya: (1) Sadeghian, J. B. (1991) tentang Communicative Competence in English Language Teacing, (2) Astika, G. (2004) tentang English syllabus design, (3) Faridi, A. (2008) tentang The material design of the English course for elementary schools, dan (4) Rukmini, D. (2007) tentang The rhetorical development realization, dapat disimpulkan bahwa pengajaran dan pembelajaran bahasa Inggris termasuk di dalamnya kurikulum, silabus, materi ajar/kompetensi, media dan strategi, dan assesmen perlu didasarkan atas kajian/ temuan ilmiah (Empirical Findings).

Keberhasilan penggunaan bahasa untuk komunikasi tidak bisa dilepaskan dari perkembangan communicative competence dari pengguna bahasa itu sendiri. Selain itu, juga dipengaruhi oleh the sociocultural norms of the society tempat bahasa itu dipakai atau digunakan. Hal ini sudah muncul tiga dekade yang lalu sejak pertama kali pendekatan komunikatif atau communicative approach dipakai dalam pengajaran bahasa. Dalam beberapa program bahasa, para language educators dan 
peneliti/pengembang kurikulum bahasa telah mengimplementasikan communication-oriented teaching design untuk menciptakan dan mengembangkan cara atau metode yang lebih efektif dalam meningkatkan students' communication skills sebagai jawaban atas pembelajaran bahasa terdahulu yang berorientasi pada grammatical knowledge.

Desain kurikulum bahasa Inggris juga seharusnya berbasis pada teori terkini atau pendekatan yang relevan tentang Communicative Competence in English Language Teaching (ELT). Harapannya, kurikulum tersebut mampu menghasilkan peserta didik yang menguasai Communicative English Skill.

Kurikulum yang desain dengan baik dan benar akan berimplikasi pada hal-hal berikut. Pertama, desain yang dikembangkan berimplikasi pada perhatian para ahli pendidikan bahasa akan pentingnya teori terkini tentang Communicative Competence in English Language Teaching (ELT) yang dijadikan sebagai basis pengembangan. Termasuk di dalamnya teori Curriculum and Syllabus Design berbasis The Empirical Findings dengan mengidentifikasi ragam jenis Competence dan Tasks yang dibutuhkan oleh peserta didik. Selain itu, desain tersebut harus mampu mengakomodir Knowledge dan Skill yang penting dan relevan serta dibutuhkan. Kedua, desain kurikulum yang baik, akan mampu menjawab atau memenuhi kebutuhan pedagogik peserta didik akan knowledge and skills yang sesuai atau relevan terutama pada aspek pedagogik dalam proses pengajaran dan pembelajaran di kelas. Ketiga, desain kurikulum yang baik harus dapat mengubah (change) aspek pedagogy of information-transmission kearah pedagogy of communicative skill.

Beberapa penelitian tentang sosiokultural dalam pembelajaran bahasa di antaranya: (1) Li (2004) dari New Zealand, menemukan bahwa tidak semua murid Asia puas dengan pengalaman belajar mereka.
Hal itu tidak mengejutkan karena mereka berasal darinegara yang mempunyai sosiokultural, etnis, dan latar belakang keluarga yang berbeda dengan New Zealand; 2) ) Lengkanawati, N S. (2004) dari Indonesia, mengadakan penelitian terhadap perbedaan penggunaan strategi dalam pembelajaran bahasa asing dikarenakan latar belakang sosiokultural yang berbeda.

Untuk mendapatkan titik temu antara pembelajaran bahasa Inggris formal dan pemerolehan bahasa, Krashen dan Terrel (1993:31-37) menyarankan beberapa hal: (a) kegiatan pemahaman bahasa seharusnya diberikan sebelum kegiatan penggunaan bahasa, (b) silabus seharusnya dibuat berdasarkan tema, bukan struktur kalimat, dan (c) kegiatan proses belajar mengajar seharusnya dibuat menarik, dan suasananya kondusif. Lebih lanjut dikatakan bahwa kegiatan belajar yang melibatkan interaksi dengan orang lain akan membantu siswa memahami aspek bahasa. Pemberian latihan yang diulangulang merupakan metode yang efektif untuk memancing pemahaman. Jika pembelajaran bahasa target dilakukan dengan cara ini, hasilnya akan sangat menggembirakan.

Communicative competence merupakan kompetensi pembelajaran bahasa Inggris yang mutlak diperlukan, dari tingkat yang paling rendah (SD) sampai yang paling tinggi (perguruan tinggi) yang tentunya dengan penekanan yang berbeda. Communicative Competence juga sudah menjadi target pembelajaran sejak periode pendekatan komunikatif (communicative approach) pada tahun 1994 hingga tahun 2004 (Competence Based Curriculum) dan 2006 (KTSP) dengan pemahaman bahwa pembelajaran bahasa dimulai dari teori bahasa sebagai alat komunikasi. Di dalam pendekatan communicative competence, tujuan pembelajaran bahasa Inggris diarahkan pada penguasaan kompetensi komunikatif. 
Berawal dari Richard dan Rodgers (1996: 69) mengutip apa yang dikatakan Hymes sebagai kompetensi komunikatif' yang berbeda dari pengertian "kompetensi" yang dikemukakan oleh Chomsky. Communicative approach atau pendekatan komunikatif atau pembelajaran bahasa komunikatif adalah nama yang diberikan pada seperangkat cara yang tidak hanya menguji kembali aspek apa yang perlu diajarkan dalam pembelajaran bahasa, tapi juga suatu giliran penekanan (emphasis) dalam pembelajaran.

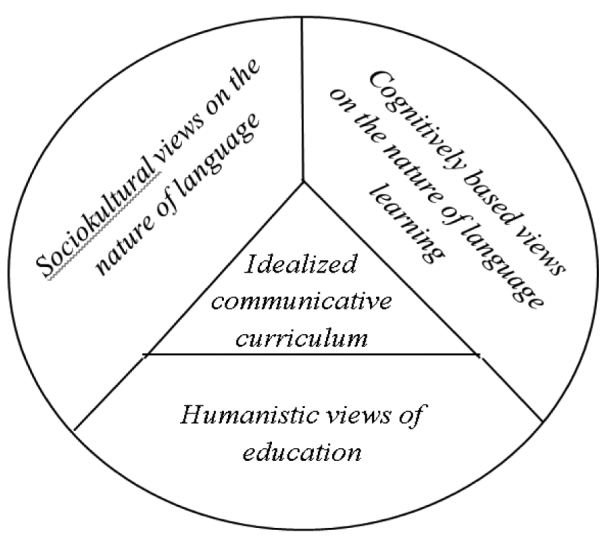

Gambar 1.

An Idealized Communicative Curriculum and the Theoretical Views which Influence it

(Dubin, Fraida, dan Olshtain, 1997:68)

Pembelajaran bahasa Inggris diharapkan mampu mengahasilkan peserta didik yang memiliki kesadaran tentang hakikat dan pentingnya bahasa Inggris untuk meningkatkan daya saing bangsa dalam masyarakat global (Diknas 2006: 403). Kurikulum yang komunikatif, didasari dari tiga ranah yang berbeda, yakni; pandangan mengenai sifat alami bahasa yang ditinjau dari sudut pandang sosiokultural, pandangan pembelajaran bahasa yang berbasis kognisi dan pendekatan humanistic dalam pembelajaran. Teori pandang yang menyangkut tujuan dari pembelajaran komunikatif dapat dilihat pada Gambar 1.
Kebudayaan sebagai seperangkat perilaku yang mendarah daging dan mode dari persepsi, menjadi sangat penting dalam mempelajari bahasa kedua. Bahasa adalah bagian dari kebudayaan, dan sebuah kebudayaan adalah bagian dari sebuah bahasa. Kedua hal ini berjalin dengan rumit sehingga seseorang tidak dapat memisahkan keduanya tanpa kehilangan arti dari kebudayaan maupun bahasa tersebut.Untuk itu, di dalam mempelajari bahasa kedua seseorang harus menyertakan pula budaya yang dimiliki oleh bahasa kedua.

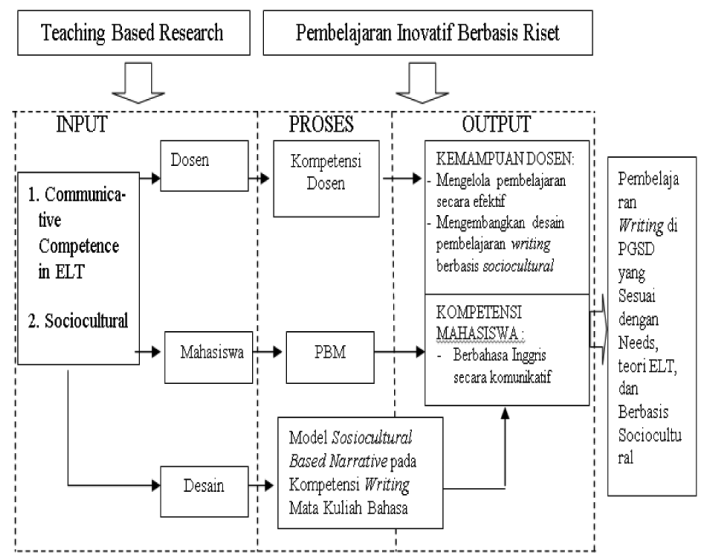

Gambar 2

Desain pembelajaran bahasa Inggris berbasis sosiokultural

Teori sosiokultural merupakan teori yang menekankan bahwa lingkungan sosial dapat membantu proses pembelajaran. Teori sosiokultural menganggap bahwa masyarakat dan budaya sebagai sumber ilmu. Kebiasaan sosial, kepercayaan, nilai dan bahasa merupakan bagian yang membentuk identitas dan realita seseorang. Pola pikir seseorang didasarkan pada latar belakang sosial-budayanya. Hal tersebut diperkuat dengan pernyataan dari Vygotsky (Kozulin, 2003: 246) Learning awakens a variety of internal developmental prosesses that are able to operate only when the child is interacting with people in his environment and in cooperation with 
people. Pendapat tersebut dikuatkan oleh Vygotsky (Schunk, 2012:243) mengungkapkan ada beberapa poin-poin utama yang harus diperhatikan terkait pandangannya mengenai teori sosiokultural yaitu:

(1) Social interactions are critical; knowledge is coconstructed between two or more people; (2) Self-regulation is developed through internalization (developing an internal representation) of actions and mental operations that occur in social interactions; (3) Human development occurs through the cultural transmission of tools (language, symbols); (4) Language is the most critical tool. Language develops from social speech, to private speech, to covert (inner) speech; (5) The zone of proximal development $(Z P D)$ is the difference between what children can do on their own and what they can do with assistance from others. Interactions with adults and peers in the ZPD promote cognitive development.

Hal itu menunjukkan bagaimana pentingnya interaksi sosial dari peserta didik baik di lingkungan sekolah maupun di masyarakat guna membangun kerjasama sebagai suatu proses pengembangan diri.

\section{METODE}

Penelitian ini merupakan penelitian pengembangan (Reasearch and Development atau R \& D). Dalam penelitian ini, model yang dihasilkan adalah "bahan ajar muatan lokal bahasa Inggris SD yang berwawasan sociocultural-based model". Proses penelitian pengembangan ini ditempuh melalui sepuluh langkah sebagaimana yang dikemukakan oleh Borg dan Gall (1983: 775-776). Desain penelitian yang telah dikemukakan tersebut kemudian dikelompokkan kedalam tiga tahap, yaitu: (1) tahap eksplorasi, (2) tahap pengembangan draft dan penilaian ahli, (3) ujicoba model, dan (4) tahap validasi model.Tahap eksploratif bertujuan untuk memotret model bahasa Inggris terdahulu, teori terkini, dan analisis kebutuhan. Tahap pengembangan draft diwujudkan dalam bentuk pengembangan $\mathrm{draft} /$ prototype model menggunakan research of best practices, yaitu penelitian yang dilakukan untuk memperoleh model terbaik diantara model-model yang telah ada. Dalam tahap ini model yang dihasilkan yaitu Sosiocultural Based Narrative pada kompetensi Writing Mata Kuliah Bahasa Inggris di PGSD. Setelah itu dilakukan penilaian produk oleh ahli (expert judgement) terhadap produk yang dikembangkan. Penilaian dan saran ahli tersebut dipakai untuk merevisi produk. Selain itu juga dilakukan focus group discussion di antara peneliti dan praktisi pembelajaran bahasa inggris.

Tahap selanjutnya yaitu tahap ujicoba produk dilakukan dengan pengujian melalui teknik quasy experiment di kelas B, D, dan F PGSD. Uji coba tahap terbatas berlangsung selama 1 bulan, yaitu bulan September 2013. Kegiatan dalam penelitian ini diwujudkan dalam bentuk uji coba terbatas pada satu kelas terhadap draft/ prototype model. Uji coba operasional dilaksanakan dengan terlebih dahulu merivisi draft sesuai temuan hasil uji coba ke I termasuk masukan dan komentar ahli. Uji coba ke II dilakukan dengan cara uji coba luas yaitu diuji coba pada kelas B, D, dan F. Uji coba operasional dilakukan dengan uji coba kelas secara luas dimaksudkan untuk mengetahui efektivitas model. Uji coba tahap kedua berlangsung selama 1 bulan, yaitu bulan Oktober 2013. Subjek penelitian yaitu dosen dan mahasiswa kelas B, D, dan F PGSD.

Teknik pengumpulan data menggunakan: (1) analisis terhadap desain perkuliahan bahasa Inggris terdahulu dan kajian teori (2) wawancara untuk need analysis baik dari dosen maupun mahasiswa, (3) penilaian produk oleh ahli, termasuk saran atau masukan, (4) pre-test dan post-test prestasi belajar mahasiswa dalam pembelajaran writing mata kuliah 
bahasa Inggris. Data kualitatif kemudian dianalisis menggunakan Analisis Deskriptif Interaktif. Menurut Milles \& Huberman (1992:100), analisis interaktif ini merupakan analisis data melalui tiga komponen, yaitu reduksi data, sajian data, dan penarikan simpulan. Selanjutnyadata kuantitatif dianalisis menggunakan uji-t (t-test) dan analisis Anova.

\section{HASIL DAN PEMBAHASAN}

Penelitian pengembangan model sosiocultural based narrative pada kompetensi writing mata kuliah bahasa Inggris di PGSD merupakan suatu penelitian yang menghasilkan model sosiocultural based narrative pada kompetensi writing mata kuliah bahasa Inggris yang layak digunakan dalam proses pembelajaran bahasa Inggris di PGSD. Model materi tersebut dikembangkan dengan mengacu pada kebutuhan guru dalam pembelajaran bahasa Inggris sebagai mata kuliah program SI PGSD. Model kompetensi writing mata kuliah bahasa Inggris lama yang telah digunakan dianalisis. Kelebihan dan kelemahan yang ditemukan digunakan sebagai dasar pada pengembangan model yang dirancang. Meskipun demikian, pengembangan model tersebut juga didasarkan pula pada teori-teori yang relevan.

Desain model sosiocultural based narrative pada kompetensi writing mata kuliah bahasa Inggris yang dikembangkan ini disusun dalam tiga tahap, yakni (1) tahap eksplorasi, (2) tahap pengembangan prototipe dan penilaian ahli, dan (3) tahap ujicoba dan validasi model. Tahap-tahap tersebut lebih lanjut dipaparkan pada bagian berikut.

\section{Model Pembelajaran Narrative Writing Terdahulu}

Berkenaan dengan penentuan skenario perkuliahan khususnya pada kompetensi writing, secara umum masalah dimaksud meliputi cara penentuan jenis materi, kedalaman, ruang lingkup, urutan penyajian, perlakuan (treatment) terhadap materi perkuliahan. Masalah lain adalah memilih sumber dari mana materi ajar itu didapatkan/dikembangkan.

Ada kecenderungan sumber materi dititikberatkan pada buku cetak saja. Padahal banyak sumber materi ajar selain buku yang dapat digunakan. Namun karena keterbatasan fasilitas di kampus, dosen jarang bisa menggunakan surat kabar, majalah, dan VCD interaktif, bahkan aspek sosiokultural yang tentunya dapat memperkaya khasanah mahasiswa dalam mengembangkan keterampilan narrative writing nya.

Selain itu, termasuk masalah yang sering dihadapi berkenaan dengan pengembangan model pembelajaran di mana dosen memberikan materi/bahan ajar terlalu luas atau terlalu sedikit, terlalu mendalam atau terlalu dangkal, urutan penyajian yang tidak tepat, dan jenis materi ajar yang tidak sesuai dengan kompetensi yang ingin dicapai oleh mahasiswa. Akibatnya, hasil dari pembelajaran yang dilakukan menjadi kurang maksimal. Imbasnya dalam pembelajaran mahasiswa mengalami kesulitan dalam mengikuti pembelajaran. Bisa juga mahasiswa merasa patah semangat dalam mengikuti pembelajaran yang dikemas dengan seakan-akan menjadi pembelajaran yang menyulitkan dan tidak menyenangkan, sesuai dengan konsep pelaksanaan pembelajaran bahasa Inggris secara joyful and meaningful learning.

Melalui wawancara, pada tahap need analysis diperoleh keterangan bahwa desain materi pembelajaran writing yang telah dikembangkan oleh dosen selama ini masih berupa materi pembelajaran yang bersifat parsial. Padahal pembelajaran bahasa yang paling efektif, untuk saat ini, adalah pembelajaran dengan pendekatan integratif, yaitu penguasaan bahasa diintegrasikan dengan kompetensi lain termasuk aspek sosial budaya. Sebagaimana dikatakan Huber \& Hutchings 
(2008:1), pembelajaran integratif memberikan kesempatan kepada peserta didik untuk menghubungkan pengalaman dan pengetahuan sehingga peserta didik lebih mudah menyelesaikan masalah dan memenuhi kebutuhan mereka akan pengetahuan. Senada dengan hal diatas, Min, et al. (2012:23-30) mengatakan bahwa tingginya tingkat pemahaman keterampilan hidup sangat dipengaruhi oleh pendekatan pembelajaran terintegrasi dengan lingkungan kehidupannya.

Hasil kajian Fogarty (1991), terungkap bahwa munculnya pemikiran tentang pendekatan integratif dipicu oleh sejumlah persoalan pendidikan yang perlu segera diatasi. Pemikiran tersebut dimunculkan dengan pertimbangan: (1) kegiatan pendidikan harus bersifat otentik, (2) kegiatan pendidikan harus bermakna, (3) kegiatan pendidikan harus efisien, dan (4) layanan pendidikan diperuntukkan bagi kepentingan peserta didik. Selain itu, dalam penerapan kurikulum dan pembelajaran bahasa, konsep pendekatan integratif memiliki tiga tipe, yaitu: (1) tipe kurikulum keterampilan berbahasa integratif, (2) tipe kurikulum integratif, dan (3) tipe integrasi di dalam dan di luar sekolah.

Berbagai aktivitas belajar pada semua tipe integratif tersebut dihubungkan oleh sebuah tema. Tema merupakan payung keterpaduan dari berbagai kegiatan belajar sehingga satu sama lain memiliki keterkaitan yang erat. Sebagai sebuah jembatan antar kegiaan belajar, tema dapat berupa masalah, kasus, wacana, karya sastra, atau proyek. Penggunaan tema yang sangat menonjol dalam pendekatan integratif ini mengakibatkan pendekatan ini kerap disebut juga sebagai Pendekatan Tematik. Secara singkat, ketiga tipe pendekatan integrasi dalam bahasa tersebut dapat disajikan pada Gambar 3.

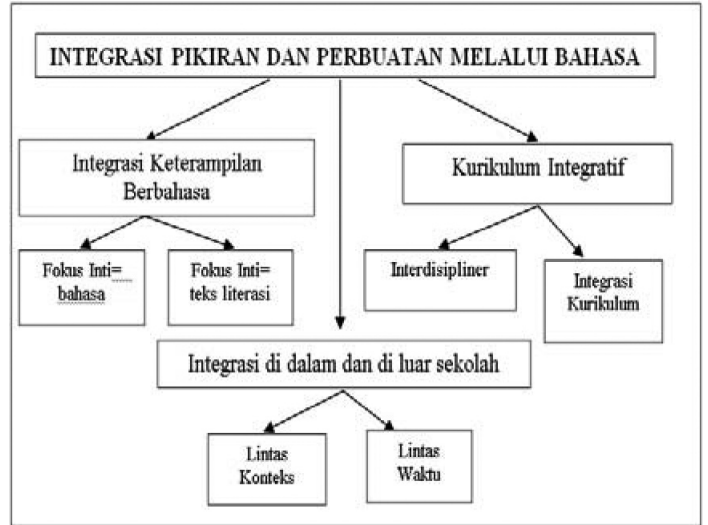

Gambar 3.

Desain Pendekatan Integratif Bahasa

Berkaitan dengan hal tersebut pengembangan materi ajar yang telah dikembangkan oleh dosen diwujudkan dalam bentuk dialog langsung, teks, tanya jawab, membaca dan menirukan, reading and tenses, praktik percakapan langsung, perkenalan diri dan keluarga, percakapan sehari-hari dan lain-lain. Materi yang dikembangkan pengembangan kompetensi writing adalah latihan menuliskan nama-nama benda di sekitar, anggota tubuh, dan keluarga, menulis kalimat sederhana, menulis paragraf, menulis cerita yang pernah dibaca atau didengarkan dengan bahasa sendiri, membuat karangan pengalamn pribadi, dan sebagainya.

Sementara itu, materi ajar yang bersifat utuh dalam bentuk buku diwujudkan dengan pemanfaatan materi ajar yang sudah dipublikasikan di pasaran yang tentunya jauh dari aspek sosiokultural. Desain pembelajaran termasuk desain materi ajar seharusnya disusun sendiri oleh dosen yang tentunya memperhatikan teori-teori terkini, input mahasiswa, dan aspek sosiokultural mahasiswa. Untuk itu, melalui pengembangan materi ajar khususnya pada kompetensi Narrative Writing yang berwawasan sosiokultural ini diharapkan pembelajaran writing tentang narative mudah diserap dan dikuasai. Pada prinsipnya manusia tidak bisa lepas dari orang lain terutama dalam memben- 
tuk jati diri, seperti yang diungkapkan Allahyar \& Nazari (2012: 25-28) bahwa perkembangan kognitif peserta didikjuga terjadi melalui partisipasi dipandu dalam interaksi sosial dengan orang yang lebih berpengalaman.

Dari kegiatan need analysis pada studi eksplorasi, diketahui bahwa dosen belum membuat atau merancang materi ajar pembelajaran writing yang berbasis sosiokultural. Selain itu dosen juga sangat membutuhkan model pembelajaran writing yang berwawasan sosiokultural sehingga pengembangan pembelajaran dapat bermakna khususnya bagi mahasiswa.

Selain itu, dari hasil wawancara dengan mahasiswa juga didapatkan bahwa respondenmenginginkan desain pembelajaran writing yang dapat menunjang profesi mereka nantinya yaitu sebagai guru kelas Sekolah Dasar dimana selain mereka harus menguasai bahasa Inggris, mereka juga harus mampu mengajar menggunakan bahasa Inggris atau mengajarkan bahasa Inggris di kelasnya. Mahasiswa berpendapat proses pembelajaran yang ada belum optimal dan masih bersifat general English belum mencakup aspek sosiokultural dan juga aspek English for Elementary School Students.

\section{Diskripsi Peta Kebutuhan Pembelajaran Bahasa Inggris}

Analisis tentang kebutuhan pembelajaran bahasa Inggris di PGSD tidak akan terlepas dari perkembangan kebijakankebijakan terkait pembelajaran bahasa Inggris. Pembelajaran bahasa Inggris di PGSD mencakup dua ranah. Pertama, general English yakni bagaimana mahasiswa mampu menguasai bahasa Inggris secara aktif baik spoken maupun writtenuntuk mahasiswa. Kedua, English for elementary school students yakni bagaimana mahasiswa mampu mengajar di kelas SD menggunakan bahasa Inggris sebagai bahasa pengantar pembelajaran dan juga bagaimana mahasiswa mampu mengajarkan materi bahasa Inggris di kelas SD nantinya kalau mereka sudah menjadi guru kelas di masa yang akan datang.

Mengenai kebijakan pada ranah yang ke-2 ini, beberapa Sekolah Dasar (SD) melaksanakan pembelajaran bahasa Inggris sebagai Mulok dan juga sebagai kegiatan ekstrakurikuler terutama setelah diberlakukanya kurikulum 2013. Keragaman penentuan kebijakan tersebut diwujudkan dari kebijakan yang mengatur tentang tingkat kelas dimulainya pembelajaran bahasa Inggris, tahun dimulainya pembelajaran bahasa Inggris, banyaknya jam pelajaran bahasa Inggris.

Sebagai data pendukung, kebijakan SD mengenai guru yang mengajarkan mata pelajaran bahasa Inggris, dari 195 responden diperoleh keterangan sebagaimana disajikan pada Tabel 1.

Tabel 1. Persentase Guru Bahasa Inggris di SD

\begin{tabular}{lcc}
\hline \multicolumn{1}{c}{ Jenis Guru } & Persentase & Frekuensi \\
\hline Guru Kelas & $21,5 \%$ & 44 \\
Guru Bidang & $75,5 \%$ & 151 \\
Studi & $97,0 \%$ & 195 \\
Total & & \\
\hline
\end{tabular}

Berdasarkan Tabel 1 tampak bahwa selain diampu oleh guru bidang studi, pelajaran bahasa Inggris di SD juga diberikan oleh guru kelas. Karena itu, dapat dimaklumi bila guru mendapat kesulitan dalam mengembangkan materi, khususnya yang berhubungan dengan keadaan sosiokultural di sekitarnya. Banyak jawaban dari angket yang menyarankan dimasukkannya masalah sosiokultural, dari hal nama tokoh, benda-benda, permainan, peristiwa budaya dan cerita-cerita rakyat, dll.

\section{Pembelajaran Writing di PGSD}

Penerapan kurikulum dalam praktik pembelajaran bahasa Inggris di PGSD dilaksanakan secara mandiri oleh masing- 
masing individu dosen termasuk desain dan metode pembelajaranya. Dari sisi isi atau contain materi terutama kompetensi writing belum memasukkan aspek sosiokultural sehingga proses pembelajaranya masih bersifat umum dan kurang sesuai dengan kebutuhan mahasiswa. Umumnya pembelajaran dilakukan secara klasikal dengan menggunakan metode dan langkah pembelajaran yang konvensional yaitu dosen menentukan topik kemudian mahasiswa praktek writing.

Dari hasil kajian literature, pembelajaran writing seharusnya menggunakan metode yang sesuai dengan karakteristik kompetensiya. Salah satu metode yang sesuai yaitu menggunakan empat learning cycles yang terdiri dari: building knowledge of the field, modeling of text, joint construction, dan independent construction.

Dalam pengembangan pembelajaran writing, dosen belum memperhatikan teori terkini dalam English language teaching yaitu teori Communicative Competence yang terdiri dari empat kompetensi yang harus dikuasai mahasiswa. Ke-4 kompetensi tersebut yaitu: grammatical competence, sociolinguistic, discourse competence, and strategic competence.

\section{Desain Model Sosiocultural Based Nar- rative Writing}

Pengidentifikasian kemampuan dosen dalam menyusun materi ajar memberikan masukan untuk menyusun model desain pembelajaran writing yang berwawasan sosiokultural. Untuk itu, diperlukan panduan yang dapat digunakan sebagai pedoman dalam penyusunan. Pedoman ini didasarkan pada teori communicative competence dalam ELT dan sosiokultural di mana pembelajaran bahasa Inggris ini dilakukan.

Pengembangan model pembelajaran writing bahasa Inggris berwawasan sosiokultural dikembangkan dengan mempertimbangkan enam aspek, yaitu: (1) acuan pengembangan (dasar pemikiran),
(2) isi materi, (3) organisasi materi, (4) pengembangan materi, (5) penyajian, dan (6) evaluasi. Enam aspek tersebut diuraikan pada bagian berikut ini.

Pertama, acuan pengembangan (dasar pemikiran). Pengembangan desain pembelajaran writing bahasa Inggris di PGSD hendaknya menggunakan acuan yang lengkap, yaitu: (1) kurikulum yang berlaku, (2) teori-teori yang relevan, seperti teori pendidikan dan pengajaran bahasa, psikologi belajar, dan teori pengajaran sastra, (3) kebutuhan bahasa mahasiswa, (4) buku-buku atau references yang menunjang pembelajaran, dan (5) pengetahuan serta pengalaman dosen dalam merancang pembelajaran bahasa Inggris.

Bagi Halliday bahasa merupakan sistem makna (system of meaning). Artinya, ketika orang menggunakan bahasa, tindak bahasa orang tersebut adalah pengujaran makna. Dari sudut pandang ini, gramatika menjadi suatu kajian bagaimana makna dibentuk melalui penggunaan kata dan kalimat (bentuk bahasa) dan kemudian menanyakan bagaimana bentuk bahasa mewujudkan makna-makna. Dengan dasar pertimbangan inilah gramatika adalah semantik (berhubungan dengan makna) dan fungsional (berhubungan dengan bagaimana bahasa digunakan). Halliday (1994: xiv) dan Eggins (1994: 2) menyebutkannya sebagai pendekatan semantik fungsional (functional-semantics).

Berdasarkan pandangan tersebut para ahli pengajaran bahasa mengadopsi integrasi bentuk dan fungsi yang menitikberatkan pada tujuan bagaimana bahasa itu digunakan atau bagaimana orang melakukan sesuatu melalui bahasa (fungsi) atau bagaimana makna disampaikan melalui bahasa.

Kedua, berkenaan dengan isi materi. Standar kompetensi dasar diantaranya mahasiswa mampu: (1) mengenal huruf (alphabeth), (2) mengenal angka (number), dan (3) mengenal kata kongkrit, seperti kata benda, dan kata tunjuk (adverb), mi- 
salnya di atas, di bawah, di samping, ini, itu, di sini, dan di sana). Kata benda atau kosakata (vocabulary) yang berhubungan dengan warna, benda-benda di sekitarnya, buah-buahan, sayur-sayuran, makanan, minuman, nama-nama anggota tubuh, dan anggota keluarga.

Standar kompetensi lanjut adalah mahasiswa mampu menguasai empat aspek keterampilan berbahasa Inggris (English skills). Salah satu keterampilan yang dimaksud yaitu writing; mampu mengidentifikasi dan mengungkapkan frasa dan kalimat dengan bahasa Inggris dalam kehidupan sehari-hari, mampu menuliskan ide-ide yang sesuai dengan kehidupan atau sesuai dengan aspek sosiokulturalnya.

Ketiga, berkaitan dengan organisasi materi. Organisasi materi yang disajikan dalam pengembangan model Sociocultural Based Narrative Writing disusun berdasarkan strategi pembelajaran yang dikemukakan oleh Burns and Joyce (dalamHelena, 2003), yakni Building Knowledge of the Field, Modelling of the Tex, Joint Construction, and Independent Constructiont. Namun demikian, masukan dari para ahli juga menjadi bagian penting dalam penyusunan ini. Pengorganisasian materi yang disajikan tersebut mencakup: (a) building knowledge of field, (b) modelling of text, (c) joint construction of text, (d) independent construction of text, dan (e) sociocultural reinforcement

Keempat, pengembangan materi writing narrative. Materi writing narative yang berwawasan sosiokultural yang dikembangkan harus memperhatikan hal penting, yakni: (a) nama, baik nama anakanak, guru atau orang yang menjadi tokoh di dalam cerita; (b) mengaitkan kegiatan sehari-hari di lingkungan keluarga, sekolah, dan masyarakat; dan (c) memasukkan unsur-unsur sosiokultural setempat (adatistiadat, kebiasaan).

Kelima, penyajian materi. Meskipun dalam organisasi materi disebutkan bahwa model ini disusun untuk mengembangkan kompetensi writing, namun dalam penyajiannya bersifat integrative, yaitu dapat dipadukan dengan kompetensi lain, yaitu listening, speaking, dan reading. Mengingat materi yang disajikan akan menjadi model, maka hasil penelitian ini dipadukan dengan hal-hal: (a) English Language Teaching (ELT), (b) Kompetensi, (c) Need Analysis, (d) Sosiokultural, dan (e) Pendekatan Pembelajaran - The Teaching and Lerning Cycle Approach.

Kelima, berkaitan dengan Evaluasi. Evaluasi merupakan salah satu unsur penting yang harus dimiliki dalam setiap pemberian perlakukan pembelajaran. Tujuannya agar setiap selesai pembelajaran dosen dapat melakukan evaluasi guna mengetahui kedalaman pemahaman yang telah dipelajari.

Berikut ini beberapa alternatif evaluasi yang diberikan dalam pengembangan desain pembelajaran writing naratif bahasa Inggris berbasis sosiokultural. Pertama, mode evaluasi Peer Evaluation, yakni metode evaluasi yang banyak dipilih untuk saling mengasah pemahaman antar mahasiswa dengan cara koreksi silang antar kelompok atau individu mahasiswa. Kedua, mode evaluasi Portofolio, yakni metode evaluasi dengan cara memberikan penugasan kepada kelompok atau individu mahasiswa di akhir proses pembelajaran untuk membuat teks karangan naratif baik pada saat pembelajaran di kelas maupun take home task kemudian dievaluasi oleh dosen dan disampaikan kepada mahasiswa kembali sebagai progress report.

\section{Penilaian dan Uji Coba Produk}

Desain model yang telah dirancang pada tahap penelitian sebelumnya kemudian diujicobakan dalam proses pembelajaran bahasa Inggris sebagai mata pelajaran. Sebelum dilakukan uji coba, terlebih dulu model dinilai oleh ahli melalui penilaian produk ahli atau Experts 
Judgement untuk mengetahui kelayakan produk.

Pada tahap validasi model atau experts judgements melalui penilaian produk oleh ahli diperoleh masukan untuk memperbaiki pengembangan model yang telah dikembangkan. Pertama, outcome dari setiap unit kompetensinya perlu ditonjolkan. Kedua, pada bagian yang menyatakan perintah harus menggunakan satu kalimat untuk setiap perintah yang ada. Ketiga, selain pemberian keterangan pada setiap gambar yang dipakai, setiap gambar tersebut juga harus disebutkan sumbernya. Keempat, setiap tugas (Task) harus menonjolkan aspek sosiokulturalnya. Kelima, setiap contoh teks dan task writing harus memperhatikan aspek English for Elementary Schools karena mahasiswa tersebut akan menjadi guru kelas SD.

Tabel 2. Perbandingan Nilai Rata-Rata Hasil Ujicoba

\begin{tabular}{|c|c|c|c|c|c|c|c|}
\hline \multirow{3}{*}{$\mathrm{N}_{0}$} & \multirow{3}{*}{ Kelas } & \multicolumn{6}{|c|}{ Nilai Rata-Rata Mean Per Kelas } \\
\hline & & \multicolumn{2}{|c|}{ Uji coba I } & \multicolumn{2}{|c|}{ Uji coba II } & \multicolumn{2}{|c|}{ Uji coba III } \\
\hline & & Pre T & Post & Pre T & Post & Pre T & Post \\
\hline 1 & Kelas B & 73,43 & 88,10 & 76,40 & 87.83 & 71,63 & 82,83 \\
\hline 2 & Kelas D & 79,51 & 90,09 & 73,22 & 87,61 & 78,97 & 94,03 \\
\hline 3 & Kelas $F$ & 78,95 & 94,05 & 73,28 & 87,88 & 79,60 & 90,33 \\
\hline
\end{tabular}

Setelah penilaian produk oleh ahli dan produk telah dinyatakan layak, dilakukan uji coba produk di kelas melalui quasy-eksperimen dengan tujuan untuk mengetahui pengaruh model pembelajaran yang telah dibuat. Hasil pembelajaran bahasa Inggris yang berwawasan sosiokultural yang diterapkan oleh dosen dengan mengacu pada materi ajar yang telah dirancang melalui penelitian ini disajikan pada Tabel 2.

Tabel 2 menunjukkan bahwa pemerolehan nilai mean atau rata-rata dari pre-test dan post-test mengalami peningkatan. Pada uji coba tahap I, kelas experimen 1 mengalami peningkatan dari nilai rata-rata 73,43 menjadi 88,10. Untuk kelas ekperimen 2, peningkatan nilai rata-rata yang diperoleh 76,40 menjadi 87,83 . untuk kelas kontrol diperoleh nilai rata-rata 71,63 menjadi 82,83 .

Kondisi serupa juga dialami pada uji coba tahap II, terjadi peningkatan nilai rata-rata yang diperoleh kelas experimen 1 sebesar 79,51 menjadi 90,09. Sementara itu, nilai rata-rata kelas eksperimen 2 yang diperoleh sebesar 73,22 menjadi 78,97 dan kelas kontrol diperoleh nilai 78,97 menjadi 94,03 . Hasil uji coba ke II dengan menggunakan model pembelajaran writing yang dikembangkan berdasarkan sosiokultural menunjukkan adanya peningkatan nilai mean-nya.

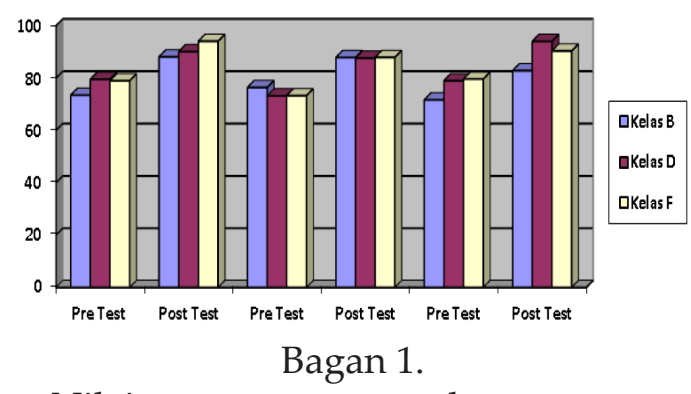

Nilai rata-rata pre-test dan post-test

Hasil uji coba ke III yang diterapkan di kelas juga menunjukkan kondisi yang sama, yakni peningkatan nilai rata-rata yang diperoleh secara klasikal. Pada kelas eksperimen 1 peningkatan nilai rata-rata diperoleh dari pre-test nilai 78,95. Pada post test pemerolehan nilai rata-rata tersebut dapat meningkat menjadi 94,05. Peningkatan serupa juga sama dialami oleh kelas eksperimen 2 dimana nilai rata-rata kelas mengalami peningkatan dari nilai rata-rata 73,28 menjadi 87,88. Sementara itu, peningkatan nilai rata-rata dari kelas kontrol juga mengalami peningkatan dari nilai rata-rata 79,60 menjadi 90,33. Peningkatan dari masing-masing kelas dari tiap-tiap uji coba dapat dilihat pada Bagan 1.

Efektivitas penggunaan model pembelajaran yang dikembangkan ditandai adanya peningkatan hasil belajar melalui 
menghitung selisih skor rerata pre-test dan post-test. Dengan asumsi distribusi normal dan diambil dari sampel secara proporsional kemudian dianalisis menggunakan analisis uji-t (uji kesamaan ratarata) (Sudjana, 1996: 242).

Dengan $\mathrm{dk}=(\mathrm{n}-1),=(30-1)=29$, nilai $\mathrm{t}_{\text {tabel }}=2,707$, $\mathrm{t}_{\text {hitung }}$ yang dihasilkan sebesar 6,57 . Berpedoman pada hipotesis yang telah dirumuskan yaitu: $\mathrm{H}_{\mathrm{o}}$ diterima jika $=-\mathrm{t}(1-1 / 2 \alpha)<\mathrm{t}_{\text {hitung }}<\mathrm{t}(1-1 / 2 \alpha)$, (n-1) dan $\mathrm{H}_{\mathrm{o}}$ ditolak jika $=\mathrm{t}_{\text {hitung }} \geq \mathrm{t}_{\text {table }}$. Atas dasar perhitungan tersebut disimpulkan bahwa $\mathrm{H}_{\mathrm{o}}$ ditolak dan $\mathrm{H}_{\mathrm{i}}$ diterima yang berarti bahwa bahwa secara signifikan skor rerata pre-test berbeda dengan skor rerata post-test. Hal itu menunjukkan bahwa kegiatan pembelajaran menggunakan model Sosiokultural Based Narrative pada kompetensi Writing mata Kuliah Bahasa Inggris di PGSD dapat meningkatkan kompetensi mahasiswa.

Selanjutnya dari hasil analisi anova dapat dinyatakan sebagai berikut. Berdasarkan pada hasil analisis variansi dengan menggunakan SPSS 16 for windows, dapat diketahui bahwa dengan nilai sig= 0.018 kurang dari taraf signifikansi (0.05) berarti $\mathrm{H}_{0}$ ditolak. Dengan demikian dapat disimpulkan bahwa terdapat perbedaan yang signifikan antara hasil belajar mahasiswa kelas kontrol dan mahasiswa kelas eksperimen (treatment).

Hasil uji coba model melalui analisis uji-t dan analisis anova di atas menunjukkan adanya peningkatan keterampilan mahasiswa dalam menulis karangan naratif. Dengan demikian, nilai rata-rata yang diperoleh tersebut dapat dikatakan bahwa desain pembelajaran writing yang dikembangkan layak dan efektif.

\section{Pembahasan Pengembangan Produk dan Uji Coba}

Hasil uji coba model pada tahap I sampai tahap III yang telah menunjukkan peningkatan nilai rata-rata dari penggunaan desain yang dikembangkan men- dapat respon yang positif dari dosen yang memberlakukan desain tersebut. Meskipun demikian, dosen memberikan saran untuk memperbaiki model yang telah dikembangkan.

Dosen menginginkan diksi atau pilihan kosa kata yang digunakan bersifat berjenjang. Dimulai dari kata benda dan kata kerja sederhana yang biasa digunakan dan dilihat dalam kehidupan mahasiswa sehari-hari, yang kemudian secara bertahap dikembangkan ke arah yang lebih kompleks.

Saran yang disampaikan juga menyangkut masalah kompetensi. Kompetensi yang harus dikuasai mahasiswa seharusnya berjenjang dari aspek kebahasaan dasar seperti mampu mengenal letters, words, phrases, clauses, sentences. Selain itu juga ada pengelompokan kosa kata menurut jenis kata-nya yaitu Nouns, Verbs, Adjectives, and Adverbs. Kompetensi dan jenis tasks dikembangkan berdasarkan aspek sosiokultural, kompetensi komunikatif, dan English for Elementary School Students. Mahasiswa diharapkan mampu menggunakan bahasa Inggris secara aktif komunikatif dalam kegiatan sehari-hari mereka. Kemudian dapat mengidentifikasi dan mengungkapkan keadaan lingkungan ke dalam kemampuan writing.

Dalam desain ini juga dilengkapi dengan rambu-rambu perangkat pembelajaran untuk mendukung proses pembelajaran yang meliputi silabus, lesson plan, deskripsi kompetensi, media, metode pembelajaran, dan evaluasi belajar yang dimanfaatkan sebagai acuan dan batasan pada proses belajar mengajar. Perangkat tersebut berfungsi sebagai acuan dalam proses pembelajaran yang tujuannya untuk memonitor perkembangan dan mengontrol proses pembelajaran yang ada, sehingga tujuan pembelajaran dapat dicapai dengan baik.

Selanjutnya, topik yang dikembangkan pada setiap karangan teks naratif baik 
dari teks model mapun teks karangan mahasiswa harus mengandung unsur kreatif, menarik, dan meaningful. Sebagaimana disarankan oleh Krahen dan Terrel (1993), bahwa proses pembelajaran seharusnya dibuat menarik, tidak terlalu formal, (termasuk alat pembelajaran yang dipakai), harus mempunyai arti dan fungsi yang tepat. Topik setiap karangan naratif dikembangkan dari aspek sosiokultural atau potensi sosial dan budaya yang ada seperti cerita rakya, legenda, atau kreasi budaya lokal dimana mahasiswa berasal.

Gambar atau ilustrasi lebih dominan baik yang sifatnya fiksi maupun non fiksi berukuran lebih besar disesuaikan dengan tata ruang dan jumlah kata, kalimat atau teks. Gambar dan ilustrasi bersifat komunikatif untuk mendukung penjelasan kata, kalimat, atau teks. Gambar dan ilustrasi lebih banyak berwarna agar lebih menarik perhatian. Penentuan gambar dan ilustrasi mengakomodasi nama, kebiasaan, peristiwa budaya, dan bahkan cerita rakyat.

Setiap kalimat harus efektif dan bermakna. Hal ini dimaksudkan agar kalimat tersebut mudah dibaca, dicerna, dan difahami maksudnya. Mulai dari pola kalimat, jenis kalimat yaitu simple sentence, compound sentence, dan complex sentence. Pilihan kata atau diksi dalam kalimat disesuaikan dengan potensi sosiokultural yang ada sehingga dapat menstimulus peserta didik dalam mengenal, memahami, dan mencintai eksistensi kehidupan social budaya.

Bahasa merupakan alat berkomunikasi, yaitu bagaimana dapat berkomunikasi dengan orang-orang di sekitarnya, bukan untuk diri sendiri. Oleh karena itu aspek sosiokultural tidak bisa dipisahkan dari unsur bahasa. Maka perlu kiranya memahami aspek sosiokultral di mana bahasa itu digunakan. Sebagai contoh sederhana: Tidak boleh mengatakan Good noon (Selamat siang) dalam bahasa Inggris, tapi Good Afternoon walaupun dalam bahasa Indo- nesia ada. Tidak boleh menerjemahkan Selamat sore menjadi (Good Evening) dan Selamat Malam (Good Night). Untuk alasan teacher talk, yaitu apa-apa yang diujarkan oleh dosen selama mengajar, sebaiknya menggunakan ujaran yang benar, dengan pronunciation yang tepat. Ujaran itu dapat berupa pujian sederhana, seperti, That's fine! Great! That's very good! Etc. Dalam hal aspek sosiokultural lainya, sebagai contoh Yogyakarta, dapat menonjolkan unsurunsur sosiokultural Jawa seperti musik gamelan, tarian jawa. Selain itu juga dari aspek makanan seperti gudeg termasuk bagaimana berperilaku pada saat makan atau table manner ala adat Jawa seperti menggunakan tangan kanan.

Sebagimana dijelaskan sebelumnya, bahwa salah satu hasil dari needs analysis ialah kebutuhan untuk memasukkan unsur sosiokultural. Adapun salah satu bentuk materi yang disarankan ialah cerita rakyat atau folk tale. Pemanfaatan folk tale, legenda, atau cerita rakyat lokal tempat mahasiswa berasal akan sangat membantu mahasiswa dalam membuat karangan naratif. Hal itu mampu membawa emosional dan perasaan mahasiswa pada saat menulis.

\section{SIMPULAN}

Berdasarkan hasil dan pembahasan dapat disimpulkan sebagai berikut. Pertama, desain pembelajaran sociocultural based narrative pada kompetensi writing yang dikembangkan ini layak dan efektif untuk meningkatkan kemampuan writing mahasiswa di PGSD. Kedua, pengembangan desain ini dilakukan dengan mempertimbangkan: (1) acuan pengembangan (dasar pemikiran), (2) isi materi, (3) organisasi materi, (4) pengembangan materi, (5) penyajian, dan (6) evaluasi. Ketiga, pengembangan pembelajaran writing juga memperhatikan aspek teori terkini dalam ELT, yaitu teori Communicative Competence. Teori Communicative Competenceyang terdiri dari empat kompetensi, yaitu: 
grammatical competence, sociolinguistic, discourse competence, and strategic competence dan teori Systemic Functional Linguistics. Organisasi materi/kompetensi dalam desain ini juga memasukkan unsur-unsur sosiokultural setempat (adat-istiadat kebiasaan).

\section{UCAPAN TERIMA KASIH}

Artikel ini ditulis berdasarkan hasil penelitian tentang pengembangan model sosiokultural based narrative pada kompetensi writing mata kuliah bahasa Inggris. Penelitian ini dapat terlaksana atas bantuan dan dukungan dari Ketua Jurusan PPSD dan sekaligus Ketua Program Studi PGSD, Ibu Hidayati, M. Hum., beserta seluruh mahasiswa kelas B, D, F semester I PGSD FIP Universitas Negeri Yogyakarta.

\section{DAFTAR PUSTAKA}

Allahyar, N. \& Nazari, A. 2012. "Potentiality of Vygotsky's Sociocultural Theory in Exploring the Role of Teacher Perceptions, Expectations and Interaction Strategies". Journal of Environmental E Science Education, (4), 25-28.

Alwasilah, A. 1997. "Bahasa Inggris di Sekolah Dasar". Dalam Politik Bahasa dan Pendidikan. Bandung: Rosda Karya.

Astika, G. 2004. “Syllabus Design for Tour and Travel Management Department at Satya Wacana University". Dissertation. Surakarta: Sebelas Maret University.

Borg, Walter R, Meredith D. Gall. 1983. Educational Research: An Introduction. New York \& London: Longman.

Departemen Pendidikan Nasional. 2006. Pedoman Pengembangan Buku Pelajaran. Jakarta: Pusat Perbukuan.

Dubin, Fraida dan Olshtain Elite. 1997. Developing Programs and Materials for Language Learning. New York. Cambridge University Press.
Eggins, S. 1994. An Introduction to Systemic Functional Linguistics. London: Printer Publishers

Faridi, A. R. 2008. “Pengembangan Model Materi Ajar Muatan Lokal Bahasa Inggris di Sekolah Dasar Jawa Tengah yang Berwawasan Sosiokultural". Disertasi. Semarang: Universitas Negeri Semarang

Fogarty, R. 1991. The Mindful School: How to Integrate Curricula. Palatine, III: Skylight Publishing. Inc.

Halliday, M.A.K. 1994. Introduction to Functional Grammar. London: Arnold

Helena, I. R. A. 2003. Implication of the Model of Language. Semarang: Mondial Education.

Huber, M.T., \& Hutchings, P. 2008. “Integrative Learning: Mapping The Terrain International". Journal for The Scholarship of Teaching \& Learning, 2, pp. 14-20.

Irine, Siti Dwi A. 2013. “Developing Cultural Competence in The Policy of Primary Education Decentralization". Proceeding: Empowering the Primary Education for the Brighter Generation(pp.92-98). Yogyakarta: Primary Education \& Elementary School Teacher Education

Kozulin, A., et.al. 2003. Vygotsky's Educational Theory in Cultural Context. New York: Cambridge University Press.

Krashen, S. D. and Terrel. 1993. Second Language Acquisition and Second Language learning. New York: Prentice Hall

Lengkanawati, N. S. 2004. "How Learners from Different Cultural Backgrounds Learn a Foreign Language". The Asian EFL Journal. Volume 6. Issue 1: March 2004.

Miles, Mathew B. dan A. Michael Huberman. 1988. Analisis Data Kualitatif. Terjemahan Tjejep Rohendi Rohidi. Jakarta: Universitas Indonesia

Min, K. C., et.al. 2012. “Teachers' Understanding and Practice Towards Thematic Approach in Teaching In- 
tegrated Living Skillss". International Journal of Humanities and Social Science, 2, 23-30.

Li, Minsheng. 2004. "Culture and Classroom Communication: A Case Study of Asian Students in New Zealand Language Schools". TheAsian EFL Journal, 6(1): http://www.asian-efljournal.com/04_ml.php

Richards, J. C. and Rodgers, T. S. 1996. Approaches and Methods in Language Teaching. New York: Cambridge University Press.

Rukmini, D. 2007. “The Rhetorical Development Realizations of Reading Texts in the Senior High School English Text Books". Dissertation. Semarang: State University of Semarang.
Sadeghian, J. B. 1991. “Syllabus Design and Communicative Language Teaching". Dissertation. Washington, DC: Georgetown University.

Schunk, H.D. 2012.Learning Theories an Educational Perspective.Boston: Person.

Sudjana, Nana. 1996. Pembinaan dan Pengembangan Kurikulum di Sekolah. Bandung: Sinar Baru Algensindo

Vargas-Hernandez. 2013. "Strategic Management in Basic Education Institutions in Mexico". Proceeding. Empowering the Primary Education for the Brighter Generation (pp.75-82). Yogyakarta: Primary Education \& Elementary School Teacher Education 